\title{
Perceived Effects of Climate Change on Transhumance Pastoralists in Ogun State, Nigeria
}

\author{
I. F. Ayanda ${ }^{1}$, R. A. Oyeyinka ${ }^{2}$, S. A. Salau ${ }^{1} \&$ F. Ojo ${ }^{1}$ \\ ${ }^{1}$ Department of Agricultural Economics and Extension Services, Kwara State University, Malete, Nigeria \\ ${ }^{2}$ Department of Agricultural Administration, College of Agricultural management and Rural Development, \\ Federal University of Agriculture, Abeokuta, Ogun State, Nigeria
}

Correspondence: R. A. Oyeyinka, Department of Agricultural Administration, College of Agricultural management and Rural Development, Federal University of Agriculture, Abeokuta, Ogun State, Nigeria. E-mail: akinoye2009@gmail.com

Received: December 21, 2012 Accepted: February 20, 2013 Online Published: March 15, 2013

doi:10.5539/jas.v5n4p190 URL: http://dx.doi.org/10.5539/jas.v5n4p190

\begin{abstract}
The study examined perceived effects of climate change on grazing land, herds' performance and examined the coping strategies of the pastoralists to climate change. Multi-stage sampling technique was used to select 120 respondents for the study. Data were analyzed using percentages, frequencies, tables and Chi square statistical tools. The result of the study showed that $37.5 \%$ of the respondents were between the ages of 51-60 years with an average age of 49.8 years. The results revealed that $67.5 \%$ of the pastoralists strongly agreed that the pattern of rainfall in recent time affects pasture availability. Consequently $47.5 \%$ and $52.5 \%$ of them reported a decrease in milk production and increase in herd's mortality rate respectively due to the effect of climate change. A significance relationship was established between factors of climate change and milk production of the herd (calculated $\mathrm{x}^{2}=52.00$, tabulated $\mathrm{x}^{2}=7.8147 . \mathrm{p} \leq 0.05$ ). It is therefore recommended that the pastoralists be trained in forage conservation techniques. They should also be encouraged to pool their resources to enjoy economics of scale by the extension workers. Grazing reserves should be developed by the government to fast track the disposition of the pastoralists to sedentary life.
\end{abstract}

Keywords: pastoralist, climate, transhumance, change, Nigeria

\section{Introduction}

The world is witnessing the adverse effects of climate change which include frequency and intensity of storm, thunder, flood, drought, hurricanes, increased frequency of fire, poverty, malnutrition, reduced agriculture productivities, water need and supply, adverse effects on grazing land and pasture quality. Climate change also led to rise in sea level. It had a cumulative effect on natural resources and disruption of eco-system. The impact of climate change can be vast in Nigeria; this means that some stable ecosystems such as the Sahel Savanna may become vulnerable because warming will reinforce existing patterns of water scarcity, increasing the risk of drought in Nigeria and most countries in West Africa (BNRCC, 2008).

Climate change as suggested by some researchers could impact the economic viability of livestock production systems worldwide. Surrounding environmental conditions directly affect mechanisms and rates of heat gain or loss by all animals (NRC 2002). Lack of prior conditioning of livestock to weather events often results to catastrophic losses in the domestic livestock industry. The potential risk associated with livestock production systems due to global warming can be characterized by levels of vulnerability, as influenced by animal performance and environmental parameters. When combined performance level and environmental influences create a low level of vulnerability, there is little risk (e.g. rate of gain, milk production per day, etc.). However, combining an adverse environment with high performance pushes the levels of vulnerability and consequent risk to even higher levels. Inherent genetic characteristics or management scenarios that limit the animals ability to adapt to or cope with environmental factors also puts the animal at risk. It also affects the feed intake of the animal because ingestion of food is directly related to heat production, any change in feed intake and /or energy density of the diet will change the amount of heat produced by the animal. The ambient temperature has the greatest influence on voluntary feed intake. 
Climate change is attributable directly or indirectly to human activities that change the composition of the global atmosphere. It emanates from natural climate variability observed over a comparable time period (IPCC, 1996). It is obvious from the definition that climate change is an inherent attribute of climate, which is caused by both human activities (anthropogenic) and natural processes (bio geographical). As a result of climate change the pastoralists migrated from the northern part of the country to southern parts of the country including Ogun State. There are 651 pastoral households with about 5,937 people in 28 settlements in Ogun State (Omotayo, 2010). Some of the land-use practice of the pastoral Fulanis such as seasonal bush burning along the grazing orbits for regeneration of pasture, periodic movement of the huts, intensification of land use, shifting cultivation with short fallow periods and lack of commitment to investment in long-term land improvement initiatives is capable of compromising the integrity and resilience of the ecosystem (Ayoade, 2004).

\subsection{Problem Statement}

Transhumance pastoralism was originally a way of life among communities whose lives and livelihood are in separately intertwined with cattle, goats, sheep and other ruminant species that depend on natural rangeland for grazing resources. Today, in spite of the advent of monetized economy, pastoralism has remained a veritable source of livelihood and food security as cattle, goats and sheep perform economic, as well as traditional, social and exchange functions. However, the dwindling pastoral resources such as open rangelands, wetlands (Fadama land), watercourses and rivers present new challenges to pastoralism (Adamu, 2008).

The bulk of locally produced meat and milk in Nigeria are through the transhumance pastoralists. However, the productivity of their cattle over the years was low partly because of inadequate supply of pasture and water. The situation is aggravated as a result of climate change which exposed the pastoralists and their herds to tougher weather situation especially drought, poor quality pasture, inadequate water supply, risk of contacting disease, pests, conflict between the pastoralists and crop producers over land use. Furthermore, climate change reduced available land for livestock production purposes because of desert encroachment currently moving at 600 metres/annum (or 350,000 hectares per annum (IPCC, 2007). Consequently, pastoralists migrated to the southern part of the country where pasture could be found. In 2008 alone, a total of $\$ 78.026$ billion was expended on milk importation in Nigeria (National Bureau of Statistics, 2009). The reliance on food importation is described as dangerous for the nation's economy (Olayemi, 2005).

Cattle, sheep and goat performed better (in terms of calving, growth, milk production, etc) within a temperature range of between $10^{\circ} \mathrm{C}$ and $20^{\circ} \mathrm{C}$ called Comfort Zone". The average temperature range recorded in the study area was throughout the year above the comfort zone (Figure 1) under which these animals can thrive and is capable of predisposing the animals to thermal stress (McDowell, 1980). Furthermore, low and irregular rainfall pattern (Fig, 2). It was only in year 2002 and 2007 that the rainfall recorded was above $1500 \mathrm{~mm}$ which is just barely adequate to support the growth of tree crops. For most part of the period under review (1990-2010), the rainfall was generally low (below $1000 \mathrm{~mm}$ ). This situation may affect the availability of water and pasture to livestock. Similarly combinations of temperature (Figure 1) and high humidity (Figure 3) are particularly detrimental to milk production (Smith, 1980). Conducive weather conditions, water and food are important in the physiological processes of these animals.

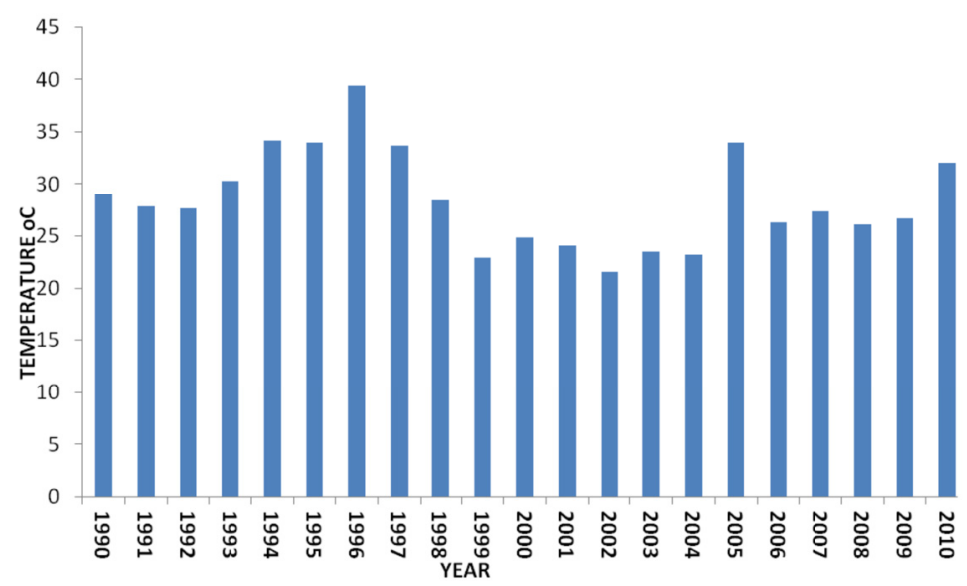

Figure 1. Average Annual Temperature for Ogun State, Nigeria (1990-2010)

Source: Ogun Osun River Basin Development Authority. Alabata Road Abeokuta. 


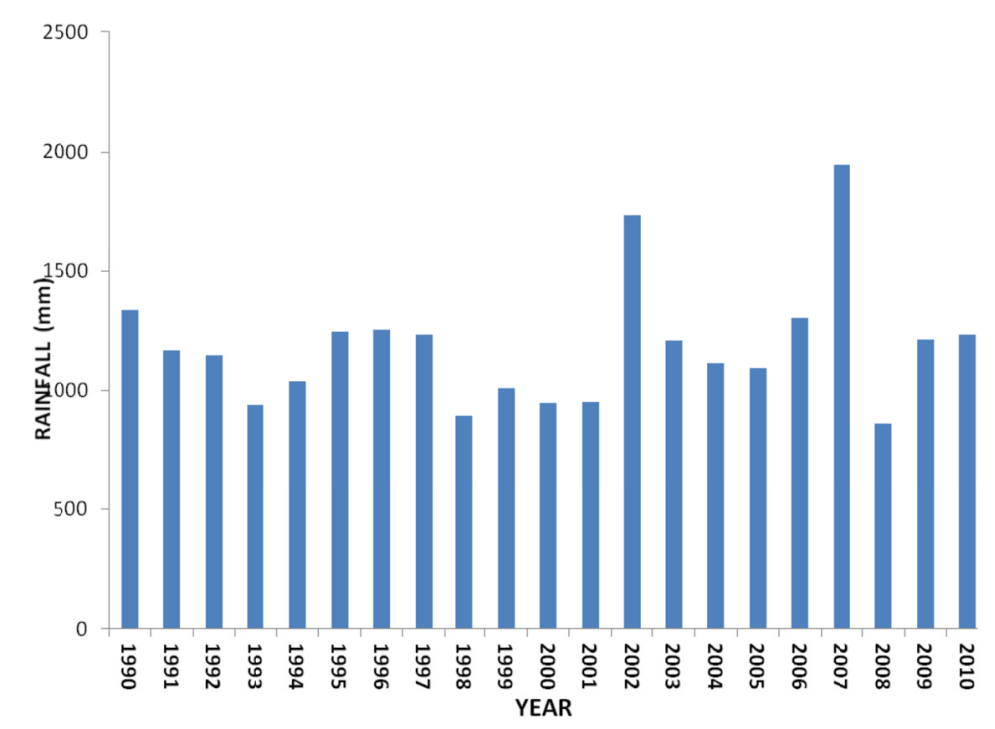

Figure 2. Average annual rainfall for Ogun State, Nigeria (1990-2010)

Source: Ogun Osun River basin development authority, Alabata Road Abeokuta.

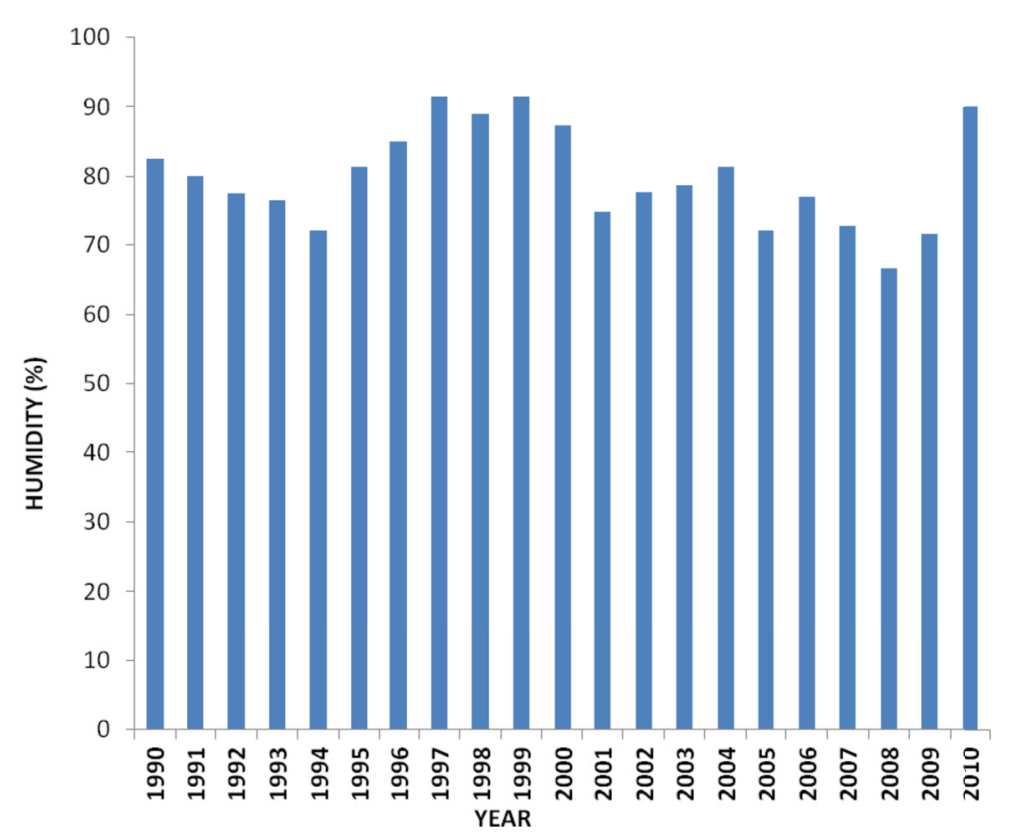

Figure 3. Average annual relative humidity for Ogun Staten, Nigeria (1990-2010) Source: Ogun Osun River basin development authority, Alabata Road Abeokuta.

\subsection{Objectives of Study}

Thus, the objectives of the study were to:

(a) examine the socio-economic characteristics of the pastoralists

(b) determine perceived effects of climate change on grazing land,

(c) investigate herds' performance due to climate and

(d) investigate the coping strategies of the pastoralist to climate change.

\subsection{Hypotheses Testing}

The following hypotheses were tested: 
(1) There is no significant relationship between socio-economic characteristics and coping strategies of pastoralists to climate change.

(2) There is no significant relationship between adverse changes in climatic factors and milk production of the herds.

\section{Materials and Methods}

\subsection{Study Area}

Ogun state was created in Nigeria in the year 1976 alongside with six (6) other states with Abeokuta as its capital. Ogun state lies between longitude $2^{\circ} 45^{\prime}$ and $3^{\circ} 55^{\prime}$ East of Greenwich Meridian and latitude $7^{\circ} 01^{\prime}$ and $7^{\circ}$ North of the Equator. It covers a land area of approximately 16,406.226 square kilometers. The State is bounded in the West by the Benin Republic, in the South by Lagos State and the Atlantic Ocean, in the East by Ondo State and in the North by Oyo and Osun States. The population of the state is 3,728,098 comprising 1,847,243 males and 1,880,855 females (NPC, 2006). The state has twenty Local Government Areas. These include Abeokuta North, Abeokuta South, Ado-Odo/Ota, Egbado North, Egbado South, Ewekoro, Ifo, Ijebu East, Ijebu North, Ijebu North East, Ijebu Ode, Ikenne, Imeko-Afon, Ipokia, Obafemi-Owode, Ogun Waterside, Odeda, Odogbolu, Remo North, Shagamu The State is naturally endowed for food and cash crop production, Agricultural production is the major means of livelihood of the people of the state. However there are influxes of pastoral Fulanis from the northern part of the country into the state probably due to climate change.

\subsection{Sampling Procedure and Sample Size}

The target population for the study was the pastoral Fulanis in the study area. The study used a multi stage sampling technique to select the respondents. Stage one involved a purposive selection of five LGAs where the pastoralists are mostly located. These include Odeda, Egbado South, Egbado North, Ipokia and Obafemi Owode. The second stage involved the random selection of four Fulanis settlements in each LGAs. The final stage was the random selection of seven Fulanis per settlement to make up a sample size of 140. However, only 120 questionnaires were returned and analyzed.

\subsection{Data Analysis}

Data were analyzed with the used of percentages, frequencies counts and Chi-square statistics.

\section{Results and Discussion}

\subsection{Socio-Economic Characteristics of the Pastoralists}

Table 1 indicated that $37.50 \%$ of the respondents were between the ages of 51-60 years with an average age of 49.8 years. At this age, Ismaila (2010) reported that pastoralists are incapable of handling tedious farming activities such as covering long distances to graze the animals. However it was observed that most respondents looked mal-nourished and older than their age. A possible explanation of their physical appearance might be the long distance covered on daily basis to feed their animals. Majority (90\%) of the pastoralists were male with an average of 29.5 years in transhumance pastoralism. The tending of cattle requires long distance travelling on daily basis. This is probably beyond the scope of the female. The result revealed that $58.8 \%$ of the respondents were married while $15 \%$ of them were widow. This indicates that there is a high mortality rate among the male pastoralists suggesting that pastoralism entails a lot of job hazards. Furthermore, $50.8 \%, 10.8 \%$ and $5 \%$ of the respondents had quranic, primary and secondary education respectively. This implies that the Fulanis are mostly adherent of Islamic faith. The average herd size was 21 . The frequent search for pasture and water might be the basis for keeping small herd size. 
Table 1. Socio-Economic characteristics of the pastoral fulanis, $\mathrm{n}=120$

\begin{tabular}{|c|c|c|}
\hline Characteristics & Frequency & Percentage \\
\hline \multicolumn{3}{|l|}{ Age (Years) } \\
\hline $21-30$ & 11 & 9.1 \\
\hline $31-40$ & 14 & 11.7 \\
\hline $41-50$ & 23 & 19.2 \\
\hline $51-60$ & 45 & 37.5 \\
\hline $61-70$ & 27 & 22.5 \\
\hline Average & 49.8 & \\
\hline \multicolumn{3}{|l|}{ Gender } \\
\hline Male & 108 & 90.0 \\
\hline Female & 12 & 10.0 \\
\hline \multicolumn{3}{|l|}{ Marital Status } \\
\hline Single & 19 & 16.2 \\
\hline Married & 71 & 58.8 \\
\hline Widowed & 18 & 15.0 \\
\hline Divorced & 12 & 10.0 \\
\hline \multicolumn{3}{|l|}{ Household Size } \\
\hline $1-05$ & 87 & 72.5 \\
\hline 6- 10 & 30 & 25.0 \\
\hline $11-15$ & 3 & 2.5 \\
\hline Average & 6 & \\
\hline \multicolumn{3}{|l|}{ Educational Level } \\
\hline No Formal Education & 35 & 28.4 \\
\hline Adult Education & 6 & 10.0 \\
\hline Quranic Education & 61 & 50.8 \\
\hline Primary Education & 13 & 10.8 \\
\hline Secondary Education & 16 & 5.0 \\
\hline \multicolumn{3}{|l|}{ Herding Experience } \\
\hline $1-10$ & 7 & 5.8 \\
\hline $11-20$ & 11 & 9.2 \\
\hline $21-30$ & 38 & 31.7 \\
\hline $31-40$ & 39 & 32.5 \\
\hline $41-50$ & 25 & 20.8 \\
\hline Average & 29.9 & \\
\hline \multicolumn{3}{|l|}{ Size of Herds } \\
\hline $1-10$ & 24 & 20 \\
\hline $11-20$ & 37 & 30.8 \\
\hline $21-30$ & 43 & 35.8 \\
\hline $31-40$ & 16 & 13.4 \\
\hline Average & 21 & \\
\hline
\end{tabular}

Source: Field survey 2011. 


\subsection{The Effects of Climate Change on Grazing Land}

Table 2, summarized the effects of climate change on pasture availability, rainfall pattern, drought and water availability. The results revealed that majority $(67.5 \%)$ of the pastoralists strongly agreed that the pattern of rainfall in recent time affects pasture availability. This implies that the pastoralists would wander a long distance in search of pasture and water. However, 50\% of the pastoralists reported that flood occurrence is not a hindering factor or constituting any threat to pasture availability. Also, about $40 \%$ of the pastoralists strongly disagreed that drought is not a common occurrence in the state while more than half of the pastoralists $(52.5 \%)$ strongly disagreed that pasture and water is readily available throughout the year in their domain. This agreed with findings of BNRCC (2008) that the impact of climate change can be vast in Nigeria. This means that some stable ecosystems such as the Sahel Savanna may become vulnerable because warming will reinforce existing patterns of water scarcity and increasing the risk of drought in Nigeria and indeed most countries in West Africa. Consequently, half $(56.2 \%)$ of the pastoralists cover a far distance to graze their animals.

Table 2. Perceived effects of climate change on grazing land, $n=120$

\begin{tabular}{llllll}
\hline Perceived effects of climate change & SA & A & U & D & SD \\
\hline Pattern of rainfall in recent time affected pasture availability & 81 & 29 & 3 & 4 & 3 \\
& $(67.5)^{*}$ & $(24.2)$ & $(2.5)$ & $(3.3)$ & $(2.5)$ \\
Prevailing temperature has no effect on the pasture & 47 & 25 & 0 & 45 & 3 \\
& $(38.8)$ & $(21.2)$ & $(0)$ & $(37.5)$ & $(2.5)$ \\
Flood occurrence hinder pasture growth & 30 & 24 & 1 & 60 & 3 \\
& $(25.0)$ & $(20.0)$ & $(1.2)$ & $(50.0)$ & $(2.5)$ \\
Drought is not a common occurrence in your location & 15 & 21 & 6 & 30 & 48 \\
& $(12.5)$ & $(17.5)$ & $(5.0)$ & $(25.0)$ & $(40)$ \\
Pasture is readily available throughout the year & 18 & 13 & 3 & 63 & 23 \\
& $(15.0)$ & $(11.2)$ & $(2.5)$ & $(52.2)$ & $(18.80)$ \\
Water is readily available throughout the year & 13 & 10 & 5 & 26 & 66 \\
You cover long distance to grace your animals & $(11.2)$ & $(8.8)$ & $(3.8)$ & $(21.2)$ & $(55.0)$ \\
& 27 & 67 & 3 & 17 & 6 \\
\hline
\end{tabular}

Source: Field Survey (2011);

*Figures in parenthesis are in percentages.

\subsection{The Effects of Climate Change on Performances of Herds}

The perceived effects of climate change on performance of the herds are shown in Table 3.

Thirty-eight percent (38\%) of the respondents strongly agreed that the herd's milk production has reduced due to climate change. Also, more than half $(52.5 \%)$ of the respondents strongly agreed that herd mortality is on the increase while (56.2\%) reported the emergence of new types of diseases. Furthermore, $60 \%$ of the respondents agreed that abortion in cattle has also increased. In addition $40.8 \%$ of the respondents reported incidence of pre and post calving mortalities in their herds. This might not be unconnected with the quality of existing pasture and the need to cover long distances under harsh weather conditions. This finding agreed with NRC (2002) that climate change could impact the economic viability of livestock production systems worldwide. Surrounding environmental conditions directly affect mechanisms and rates of heat gain or loss by all animals. 
Table 3. Perceived effect of climate change on performance of herds $(n=120)$

\begin{tabular}{llllll}
\hline Perceived effects of climate change & SA & A & U & D & SD \\
\hline Milk production has reduced & 57 & 51 & & 9 & 3 \\
& $(47.5)$ & $(42.5)^{*}$ & & $(7.5)$ & $(2.5)$ \\
Herd mortality is on the increase & 63 & 44 & & 13 & - \\
& $(52.5)$ & $(36.7)$ & & $(10.8)$ & \\
New types of diseases are noticed & 67 & 24 & 3 & 21 & 5 \\
Pre calving and post calving mortality increases in your & $(56.2)$ & $(20.0)$ & $(2.5)$ & $(7.5)$ & $(3.8)$ \\
location & $(36.2)$ & $(33.8)$ & - & 27 & 9 \\
Abortion in cattle increases & 33 & 39 & & $48.5)$ & $(7.5)$ \\
& $(27.5)$ & $(32.5)$ & & $(40)$ & - \\
Abortion in cattle decreases & 78 & 29 & - & 10 & 3 \\
& $(65.0)$ & $(23.7)$ & & $(8.8)$ & $(2.5)$
\end{tabular}

Source: Field Survey (2011);

*Figures in parenthesis represent percentages.

\subsection{Coping Strategies of the Pastoralists to Climate Change}

Coping strategy is an adjustment or self insurance pursued by the pastoralists to ensure future income generation from cattle production and minimize the adverse effects of climate change on cattle productivity. Table 4 shows that, majority of the pastoralists $(65 \%)$ engaged in sinking of open wells for the watering of their cattle, while $57.4 \%$ of the respondents reported the use of crop residue. It is important that pastoralists are exposed to technology of hay and silage making and methods of storing crop residue in order to maintain the nutritional value of these feeding stuffs. More than half (58.5\%) of the pastoralists' respondents disagreed with the migration option as a way of mitigating the adverse effects of climate change while $52.5 \%$ of them resulted to herd size reduction. More than half $(57 \%)$ of the respondents preferred the cultivation of pasture and legumes for their animal.

Table 4. Coping strategies of pastoralists to mitigate the effects of climate change $(n=120)$

\begin{tabular}{llllll}
\hline Variable & SA & A & U & D & SD \\
\hline Sinking of well & 78 & 29 & & 10 & 3 \\
& $(65)$ & $(24.2)$ & & $(8.3)$ & $(2.5)$ \\
Production of hay & 25 & 83 & - & 9 & 3 \\
& $(21.2)$ & $(68.8)$ & & $(7.5)$ & $(2.5)$ \\
Storage of crop residue & 34 & 69 & & 17 & - \\
& $(28.8)$ & $(57.4)$ & & $(13.8)$ & \\
Production of silage & 14 & 18 & - & 13 & 75 \\
& $(11.7)$ & $(14.6)$ & & $(11.2)$ & $(62.5)$ \\
Growing of pasture & 24 & 45 & - & 45 & 6 \\
& $(20)$ & $(37.5)$ & & $(37.5)$ & $(15.0)$ \\
Sinking of boreholes & 37 & 13 & 1 & 48 & 18 \\
& $(31.2)$ & $(11.2)$ & $(1.2)$ & $(40)$ & $(15.0)$ \\
Migration to conducive locations & 39 & 10 & 1 & 48 & 22 \\
& $(32.5)$ & $(8.8)$ & $(2.2)$ & $(40)$ & $(18.5)$ \\
Reduction of herd size by selling & 39 & 15 & 3 & 48 & 15 \\
& $(32.5)$ & $(12.5)$ & $(2.5)$ & $(40)$ & $(12.5)$ \\
\hline
\end{tabular}

Source: Field Survey (2011);

*Figures in parentheses represent percentages. 


\subsection{Relationship between the Adverse Changes in Climatic Factors and Performances of the Herds}

The result of Chi square analyses, in table 5 , established a significant relationship between adverse changes in climatic factors and milk production $\left(x^{2}=52.00, p \leq 0.05\right)$, herd mortality with $\left(x^{2}=20.725, p \leq 0.05\right)$, new types of diseases are noticed $\left.\left(x^{2}=53.500, p \leq 0.05\right)\right)$ and pre-calving mortality increases $\left(x^{2}=15.500, P \leq 0.05\right)$. The result confirms the findings of NRC (2002) that lack of prior conditioning of livestock to weather events often results to catastrophic losses in the domestic livestock industry. According to the findings, combining an adverse environment with high performance pushes the levels of vulnerability and consequent risk to even higher levels. Inherent genetic characteristics or management scenarios that limit the animals ability to adapt to or cope with environmental factors also puts the animal at risk. Ambient temperature has the greatest influence on voluntary feed intake. Most of the local breeds of cattle have reached their peak of production by virtue of their poor genetic make-up and unfavorable environmental situations (Amogun, 2009).

Table 5. Relationship between adverse changes in climatic factors and performances of the herds $(n=120)$

\begin{tabular}{|c|c|c|c|c|c|}
\hline Variables & $\begin{array}{l}\text { Degree of } \\
\text { freedom }\end{array}$ & $x^{2}$ calculated & $x^{2}$ tabulated & Probability & Comments \\
\hline Milk production & 3 & 52.000 & 7.815 & 0.000 & Significant \\
\hline $\begin{array}{l}\text { Herd mortality on the } \\
\text { increase }\end{array}$ & 2 & 20.725 & 5.991 & 0.000 & Significant \\
\hline $\begin{array}{l}\text { New type of diseases are } \\
\text { noticed }\end{array}$ & 3 & 53.500 & 7.815 & 0.000 & Significant \\
\hline $\begin{array}{l}\text { Pre and post-calving } \\
\text { mortality increases }\end{array}$ & 3 & 15.500 & 7.815 & 0.000 & Significant \\
\hline Abortion in cattle increases & 2 & 1.900 & 5.991 & 0.387 & Not Sig \\
\hline Abortion in cattle decreases & 3 & 2.100 & 7.815 & 0.552 & Not Sig \\
\hline
\end{tabular}

Source: Field Survey, 2011.

Table 6, also shows a significant relationship between selected socio-economic characteristics and coping strategies of the pastoralists to climate change, Age $\left(x^{2}=25.375, P \leq 0.05\right)$, marital status $\left(x^{2}=49.30, P \leq 0.05\right)$ and educational level $\left(\mathrm{x}^{2}=51.200, \mathrm{P} \leq 0.05\right)$. This finding confirms the report of Sharada et al. (2000) that both age and educational attainment are some of the important contributory factors to exposure and adoption of innovations. The youth are highly travelled, venturesome and can take risk, while educational attainment will enable them to access information on animal husbandry practices through the print or electronic media that can assist them to mitigate adverse effects of climate change. The wives can assist the husband in the marketing of animal products while the children can assist in grazing of the animals. The larger the size of the household the ease with which these tasks can be accomplished and innovations are adopted (Rogers, 2003).

Table 6. Relationships between the socio-economic characteristics of the pastoralists and coping strategies of climate change $(\mathrm{n}=120)$

\begin{tabular}{llllll}
\hline Variable & Degree of freedom & $\mathbf{x}^{2}$ calculated & $\mathbf{x}^{2}$ tabulated & Probability & Comments \\
\hline Age & 4 & 25.375 & 9.487 & 0.000 & Significant \\
Marital Status & 3 & 49.300 & 7.815 & 0.000 & Significant \\
Educational Level & 5 & 43.025 & 12.519 & 0.000 & Significant \\
\hline
\end{tabular}

Source: Field survey, 2011.

\section{Conclusion and Recommendations}

The study revealed that climate change is not only limited to the northern parts of the country but its adverse effects are noticed on the performance of herds of pastoralists (especially on milk production, herd mortality and incidence of unidentified new diseases) in Ogun State, Nigeria. The coping strategies to mitigate the adverse 
effects of climate change were inadequate to support better performance of the herd. The willingness of the pastoralists to accept a sedentary way of life through the rejection of transhumance (migration) is a welcome development. This will fast tract their access to extension services and improve on their coping approaches to mitigate the adverse effects of climate change. Therefore, the extension workers should expose the pastoralists to better approaches and coping strategies such as hay and silage making. The pastoralists should cooperate on joint use of resources for production of pasture to meet the food as well as water requirements of their herds. The grazing reserves in the state should be properly developed to encourage the pastoralists to adopt a sedentary way of life. This will enable their children to access education, urban values and mitigate the adverse effects of climate change on their herds.

\section{References}

Adamu, B. (2008). Keynote address. In J. O. Gefu, C. B. I. Alawa, \& B. Maisamari (Eds), The future of Transhumance Pastoralism in West and Central Africa. Strategies, Dynamic, Conflicts and Interventions, Proceeding of the International Conference on the Future of Transhumance Pastoralism in West and Central Africa, Abuja, Nigeria.

Amogu, U. (2009). Maximising the Animal Production Value Chain in Nigeria. Invited presentation at Nigeria Institute of Animal Science, Annual General Meeting, University of Calabar, July 28, 2009.

Ayoade, J. O. (2004). Climate Change (pp. 45-66). Ibadan: Vantage Publishers.

Building Nigeria's Response to Climate Change (BNRCC, 2008). Vulnerability, Impacts and Adaptation to Climate Change in Nigeria. 1, Oluokun Street, Bodija, U, I. P. O. Box 22025, Ibadan, Nigeria.

Intergovernmental Panel on Climate Change (IPCC). (1996). Climate Change Synthesis Report. Retrieved from www.ipcc.ch/pdf/assessment-report/a-4/pdf

Intergovernmental Panel on Climate Change (IPCC). (2007b). Impacts, adaptation and vulnerability: The Working Group II Contribution to the Intergovernmental panel on climate change fourth Assessment Report. Cambridge University Press.

Ismaila, U., A., Gana, S., Tswanya, N. M., \& Dogara, D. (2010). Cereals Production in Nigeria: Problems, Constraints, and Opportunities for betterment. African Journal of Agricultural Research, 5(12), 1341-1350. Retrieved from http://www.academicjournals.org/AJARISSN

McDowell, R. E. (1980). The Influence of Environment on Physiological Functions. In Animal Agriculture. In H. H. Cole, \& W. N. Garrett (Eds.), The Biology, Husbandry and Use of Domestic Animals (2nd ed.). San Francisco: Freeman and Company.

National Bureau of Statistics. (2009). Statistical News. Retrieved from http://www.nigerianstst.gov.ng

National Population Commission. (2006). The National Population Office, Ilorin Kwara State, Nigeria.

National Research Council (NRC). (2002). Abrupt climate change inevitable surprises. Washington, D.C.: National Academy Press.

Olayemi, J. K. (2005). "Food Security in Nigeria". Research Report No 2. Development policy centre, Ibadan, 2(32), 77-78.

Omotayo, A. M. (2010). The Nigerian Farmer and the Elusive Crown. 30th Inaugural Lecture, Federal University of Agriculture, Abeokuta, Nigeria.

Rogers, E. M. (2003). Diffusions of Innovations (5th ed.). New York Free Press.

Smith, N. E. (1980). Management of Dairy Cattle and Other Milk-Producing Cattle. In H. H. Cole, \& W. N. Garret (Eds.), Animal Agriculture, The biology, husbandry and use of domestic Animal. 